\title{
Compliance with Global Quality Requirements in Pakistan's Export Sector
}

\section{Salman Ehsan* and Ayesha Khanum ${ }^{* *}$}

\begin{abstract}
This paper describes the level of compliance with quality standards in relation to Pakistan's top export product categories. With greater competition, innovations in technology, and stricter measures of quality being enforced, Pakistan needs to adopt a holistic, systematic approach to not just meeting, but also exceeding, international quality standards and certifications for its exports. Focusing on rice and textiles, we identify which compliance-related gaps need to be filled to ensure the sustainable growth of high-quality exports to major global markets. The study outlines the key dimensions of international quality standards as well as specific standards and requirements for textiles and rice, examines the quality assurance infrastructure in Pakistan, and presents policy recommendations.
\end{abstract}

Keywords: Global quality standards, exports, compliance, Pakistan.

JEL classification: L15, P45, Q18, Q27.

\section{Introduction}

Global trade has increased manifold in the last 15-20 years with countries such as China, India, and Bangladesh having increased their exports significantly since 2000. The overall economic contribution of a country's export sector should not be underestimated: Pakistan's exports, for instance, are a major source of foreign exchange earnings and a key source of employment (Table 1).

The opportunities arising from increased global trade are accompanied by numerous challenges both for manufacturers and exporters. One of these is meeting strict quality and compliance requirements, not only from a product-specific and technical perspective, but also from regulatory, social, environmental, performance, and customer-specific standpoints. This paper provides an overview of quality standards and certification with reference to Pakistan's principal export

\footnotetext{
${ }^{*}$ Assistant Professor, Faculty of Business Administration, Lahore School of Economics.

** Assistant Editor, Lahore Journal of Economics, Lahore School of Economics.
} 
categories: textiles (specifically cotton cloth, knitwear, cotton yarn, readymade garments, and towels) and rice. It assesses their level of compliance with global requirements, identifies any gaps, and presents some policy recommendations for improving the situation. Chemicals and pharmaceuticals are seen as a potential category of export growth and thus included in our analysis in some cases.

Table 1: The textile industry's economic contribution, 2011/12

\begin{tabular}{ll}
\hline Exports & $52 \%$ of total exports (US\$ 12.36 billion) \\
Manufacturing & $46 \%$ of total manufacturing \\
Employment & $40 \%$ of total labor force \\
GDP & $8.5 \%$ of total GDP \\
Market capitalization (listed companies) & $5.0 \%$ of total market capitalization \\
\hline
\end{tabular}

Source: http://www.aptma.org.pk/Pak_Textile_Statistics/repo.asp

Historically, the textiles sector has dominated Pakistan's exports with respect to value as well as volume (Table 2). Rice represents the country's important agriculture sector and has shown significant export growth in recent years, increasing almost threefold from 2005/06 to 2011/12 (Table 2 and Figure 1). Figure 1 shows growth trends for textiles, rice, chemicals and pharmaceuticals, and total exports.

Figure 1: Pakistan's major exports, 2005-12

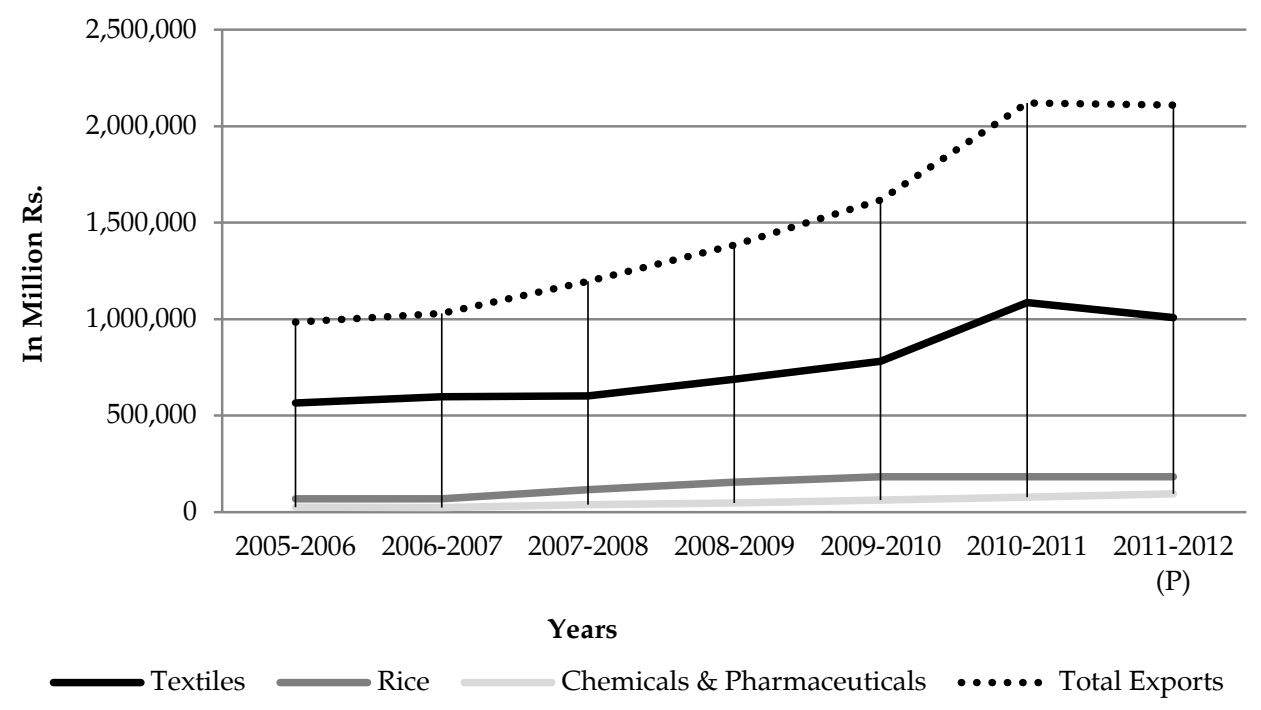

Note: $\mathrm{P}=$ provisional.

Source: Pakistan Economic Survey for 2011/12 and 2012/13. 
Table 2: Export categories

\begin{tabular}{|c|c|c|c|c|c|c|c|c|}
\hline & Top exports & $2005 / 06$ & $2006 / 07$ & $2007 / 08$ & $2008 / 09$ & $2009 / 10$ & 2010/11 & 2011/12* \\
\hline 1 & Rice & 68,786 & 68,286 & 117,088 & 154,762 & 183,371 & 183,557 & 184,405 \\
\hline 2 & $\begin{array}{l}\text { Fish and fish } \\
\text { preparations }\end{array}$ & 11,578 & 11,419 & 13,329 & 18,465 & 19,051 & 25,319 & 28,598 \\
\hline 3 & Fruits & 7,331 & 6,892 & 9,086 & 12,313 & 20,086 & 23,138 & 32,069 \\
\hline 4 & Wheat & & 5,863 & 446 & 3,064 & 61 & 49,746 & 11,179 \\
\hline 5 & Sugar & 1,591 & & 5,739 & 640 & 2 & & 2,576 \\
\hline 6 & $\begin{array}{l}\text { Meat and meat } \\
\text { preparations }\end{array}$ & 1,126 & 2,515 & 3,069 & 5,546 & 8,327 & 13,027 & 15,518 \\
\hline 7 & Raw cotton & 4,038 & 3,048 & 4,425 & 6,827 & 16,367 & 30,734 & 41,392 \\
\hline 8 & Cotton yarn & 83,490 & 86,588 & 81,321 & 87,354 & 120,069 & 186,601 & 162,003 \\
\hline 9 & Cotton cloth & 126,674 & 122,864 & 126,172 & 153,039 & 150,937 & 219,065 & 218,160 \\
\hline 10 & Knitwear & 103,876 & 115,865 & 114,481 & 135,998 & 147,866 & 196,110 & 176,681 \\
\hline 11 & Bed linen & 120,750 & 121,005 & 119,030 & 136,105 & 146,195 & 178,290 & 155,109 \\
\hline 12 & Towels & 35,699 & 36,546 & 38,453 & 50,387 & 56,012 & 64,978 & 61,326 \\
\hline 13 & Readymade garments & 79,131 & 86,965 & 93,703 & 96,483 & 106,446 & 152,858 & 144,268 \\
\hline 14 & $\begin{array}{l}\text { Made-up articles (art, } \\
\text { silk, and synthetic } \\
\text { textiles) }\end{array}$ & 11,847 & 25,464 & 25,494 & 21,740 & 37,422 & 57,103 & 48,816 \\
\hline 15 & $\begin{array}{l}\text { Carpets, carpeting, } \\
\text { rugs, mats }\end{array}$ & 15,367 & 14,147 & 13,528 & 11,392 & 11,473 & 11,285 & 10,758 \\
\hline 16 & $\begin{array}{l}\text { Sports goods excl. } \\
\text { toys }\end{array}$ & 20,569 & 17,481 & 19,012 & 21,393 & 25,021 & 27,839 & 30,242 \\
\hline 17 & $\begin{array}{l}\text { Leather excl. reptile } \\
\text { leather (tanned) }\end{array}$ & 17,293 & 20,237 & 26,026 & 23,394 & 28,699 & 39,569 & 39,841 \\
\hline 18 & Leather manufactures & 42,870 & 33,592 & 43,765 & 43,473 & 38,413 & 46,178 & 46,535 \\
\hline 19 & Footwear & 8,709 & 6,944 & 7,778 & 9,875 & 7,763 & 9,296 & 8,861 \\
\hline 20 & $\begin{array}{l}\text { Medical/surgical } \\
\text { instruments }\end{array}$ & 9,739 & 11,571 & 16,368 & 19,870 & 19,203 & 21,995 & 27,126 \\
\hline 21 & $\begin{array}{l}\text { Chemicals and } \\
\text { pharmaceuticals }\end{array}$ & 25,799 & 23,744 & 38,913 & 47,289 & 62,251 & 77,816 & 96,009 \\
\hline 22 & Engineering goods & 13,105 & 14,397 & 13,356 & 20,752 & 19,294 & 21,650 & 24,727 \\
\hline 23 & Jewelry & 966 & 2,550 & 13,477 & 22,444 & 53,456 & 34,588 & 82,774 \\
\hline 24 & $\begin{array}{l}\text { Cement/cement } \\
\text { products }\end{array}$ & 6,143 & 8,844 & 26,390 & 45,574 & 40,261 & 38,191 & 44,618 \\
\hline \multirow[t]{2}{*}{25} & All other items & 168,362 & 182,485 & 226,189 & 235,539 & 299,412 & 411,914 & 417,015 \\
\hline & Total exports & 984,839 & $1,029,312$ & $1,196,638$ & $1,383,718$ & $1,617,458$ & $2,120,847$ & $2,110,606$ \\
\hline
\end{tabular}

* Provisional exports.

Source: Pakistan Economic Survey for 2012/13.

Table 3 shows the structure of major exports from 2005 to 2012. Figure 2 shows that the textiles sector still leads among export categories, followed by rice. 
Table 3: Pakistan's major exports (PRs million)

\begin{tabular}{|c|c|c|c|c|c|c|c|c|c|c|c|}
\hline \multirow[b]{2}{*}{ Year } & \multicolumn{8}{|c|}{ Textiles } & \multirow[b]{2}{*}{ 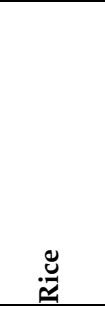 } & \multirow[b]{2}{*}{ 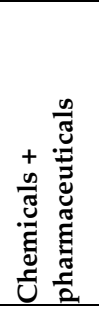 } & \multirow[b]{2}{*}{ Total } \\
\hline & 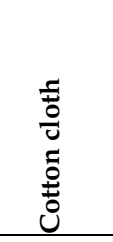 & 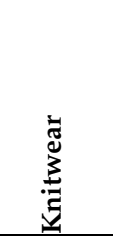 & 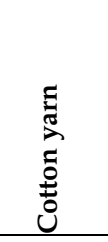 & 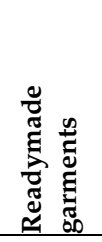 & 永 & $\begin{array}{l}\tilde{0} \\
\pm \\
0 \\
0 \\
3 \\
\text { జ }\end{array}$ & 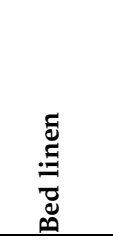 & 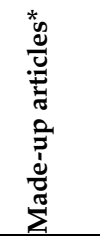 & & & \\
\hline $2005 / 06$ & 126,674 & 103,876 & 83,490 & 79,131 & 35,699 & 4,038 & 120,750 & 11,847 & 68,786 & 25,799 & 984,839 \\
\hline $2006 / 07$ & 122,864 & 115,865 & 86,588 & 86,965 & 36,546 & 3,048 & 121,005 & 25,464 & 68,286 & 23,744 & $1,029,312$ \\
\hline $2007 / 08$ & 126,172 & 114,481 & 81,321 & 93,703 & 38,453 & 4,425 & 119,030 & 25,494 & 117,088 & 38,913 & $1,196,638$ \\
\hline $2008 / 09$ & 153,039 & 135,998 & 87,354 & 96,483 & 50,387 & 6,827 & 136,105 & 21,740 & 154,762 & 47,289 & $1,383,718$ \\
\hline $2009 / 10$ & 150,937 & 147,866 & 120,069 & 106,446 & 56,012 & 16,367 & 146,195 & 37,422 & 183,371 & 62,251 & $1,617,458$ \\
\hline $2010 / 11$ & 219,065 & 196,110 & 186,601 & 152,858 & 64,978 & 30,734 & 178,290 & 57,103 & 183,557 & 77,816 & $2,120,847$ \\
\hline $2011 / 12(\mathrm{P})$ & 218,160 & 176,681 & 162,003 & 144,268 & 61,326 & 41,392 & 155,109 & 48,816 & 184,405 & 96,009 & $2,110,606$ \\
\hline
\end{tabular}

Note: ${ }^{*}=$ art, silk, and synthetic textiles; $\mathrm{P}=$ provisional.

Source: Pakistan Bureau of Statistics.

Figure 2: Overall exports of textiles, rice, and other products, 2010/11

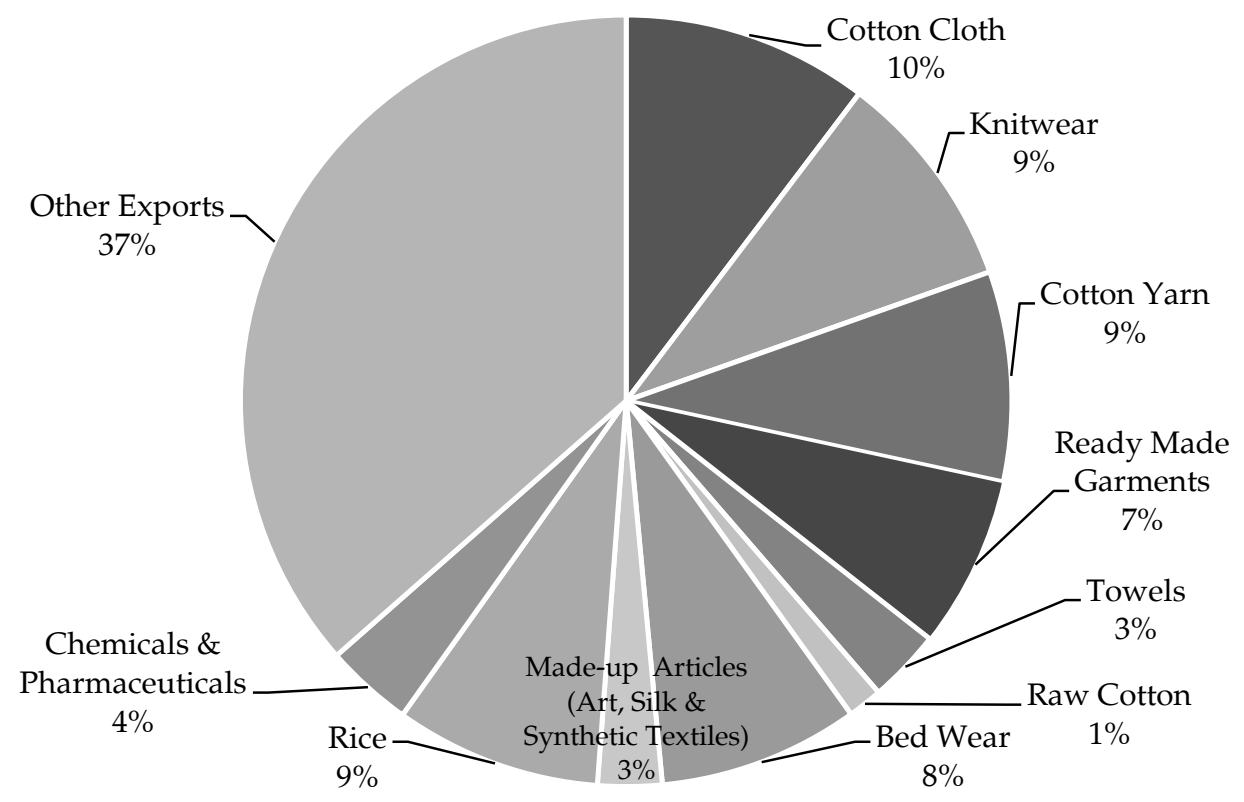

Note: Data includes provisional exports.

Source: Pakistan Economic Survey for 2012/13.

Figure 3 shows the overall growth trends for all textile categories; of these, cotton cloth has consistently trended upward. 
Figure 3: Growth trends for textile export categories, 2005-12*

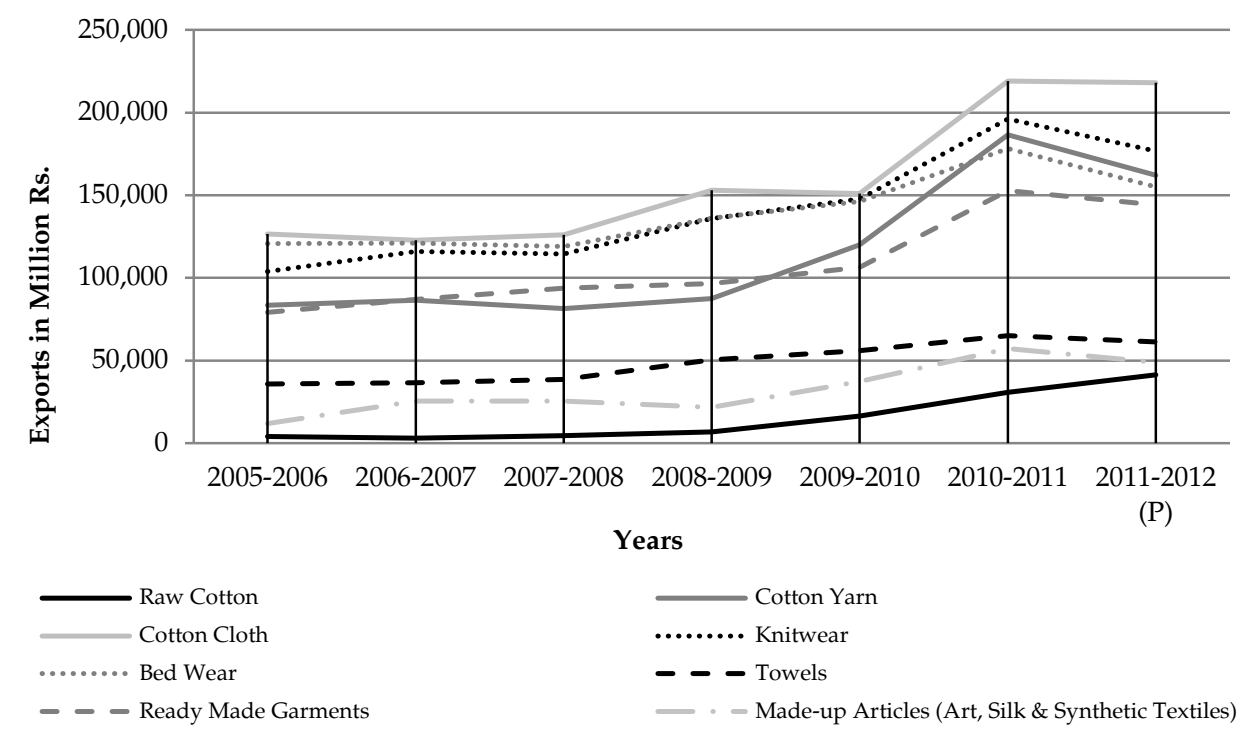

Note: ${ }^{*}=$ provisional.

Source: Pakistan Bureau of Statistics.

\section{Key Dimensions of International Quality Requirements}

This section examines the main international quality standards that apply to textile and rice exports.

\subsection{Textiles}

The requirements and standards that apply to textile exports can be categorized broadly as (i) regulatory (safety, labeling, origin, or other); (ii) product-specific (durability, performance, appearance); (iii) customerspecific (physical, chemical, or other); (iv) social (labor, facility, and work environment); and (v) environmental.

\subsubsection{Key International Quality Standards Applicable}

The main international quality standards for textile exports include the following (see Small and Medium Enterprise Development Authority, n.d.):

- ISO 9001/2000 (gaining competitive advantage through quality)

- ISO 14001 (proving the producer's environmental responsibility) 
- OHSAS 18001 (demonstrating the ability to manage risk)

- SA 8000 (enhancing a company's reputation through social responsibility)

- ISO 17799/BS 7799/BS 15000 (improving the security of a business)

- WRAP (certification of lawful, human, and ethical manufacturing)

- Eco-labels (eco-labels differ in many respects. Based on the product's scope and familiarity with the textiles sector, two labels are selected that could add value to the Pakistani industry.)

- Oeko-Tex 100 (a label that focuses on minimizing the presence of dangerous chemicals in textile products)

- EU Eco-Label for Textiles (sometimes referred to as the "European flower," it takes into account the complete lifecycle of a textile product)

- Customer-specific requirements related to facility, product, labor, and environment.

Compliance with these standards is likely to boost textile exports. They cover a range of dimensions, including technical, product-specific, safety/regulatory, performance-related, and social and environmental standards. Larger firms, particularly those conscious of their corporate image, identify their own codes of conduct, employ their own auditors, and do not rely solely on international certifications such as ISO. Such firms include, among others, Disney, Ikea, Gap, Wal-Mart, Levi Strauss \& Co., and Nike. Their own codes of conduct relate mainly to capacity, capability, safety, environment, child labor, discrimination, applicable laws, and working conditions.

Nike, for instance, follows a Restricted Substance List program and does not allow the use of heavy metals such as cadmium, azo dyes, and other chemical compounds deemed harmful for humans and/or the environment. Other global brands may insist on using organically grown cotton for their products given consumer demand and willingness to pay a premium for such products. In the case of Disney, the company employs a focused code of conduct including environmental protection and labor standards.

\subsubsection{Constraints to Meeting Quality Standards}

Our findings are based primarily on interviews with the Sapphire Group of Companies, the Chakwal Group, Matrix Sourcing, Trans-Atlantic 
Business Solutions, and Intertex. ${ }^{1}$ The key constraints identified by the business operators we interviewed are listed below:

- The lack of quality orientation and commitment to labor on the part of entrepreneurs

- Poor in-process handling, which can result in product contamination and poor appearance, and an emphasis on fixing defects downstream instead

- Inconsistent product quality

- Very few facilities that are engaged in high-quality pattern making and stitching

- The near absence of approaches to labor and human resource development

- The country's poor law and order situation, which discourages customers from visiting the industry regularly

- The high cost of energy, which, in some cases, compels producers to cut corners in process and product quality

- The dearth of high-quality raw materials and inputs needed to produce high-value consumer products

- Issues related to packaging material quality and labeling (barcodes, radio frequency identification, etc.)

- The lack of IT infrastructure, such as enterprise resource planning and electronic data interchange at the supplier level, which are critical to becoming part of high-performance global supply chains.

\subsection{Rice}

According to the Codex standards (198-1995) for rice,

Rice is whole and broken kernels obtained from the species Oryza sativa L. Paddy rice is rice which has retained its husk after threshing. Husked rice (brown or cargo rice) is paddy rice from which the husk only has been removed. The process of husking and handling may result in some loss of bran. Milled rice (white rice) is husked rice from

\footnotetext{
1 These firms were represented, respectively, by: Shayan Abdullah (owner and operator), Khawaja Shehzad (owner and operator), Azfar Hassan (chief executive officer), Mohammad Azhar (chief executive officer), and Shahid Chaudhry (chief executive officer).
} 
which all or part of the bran and germ have been removed by milling. Parboiled rice may be husked or milled rice processed from paddy or husked rice that has been soaked in water and subjected to a heat treatment so that the starch is fully gelatinized, followed by a drying process. Glutinous rice (waxy rice) [comprises] kernels of special varieties of rice, which have a white and opaque appearance. The starch of glutinous rice consists almost entirely of amylopectin. It has a tendency to stick together after cooking (Codex Alimentarius Commission, 1996).

Rice quality factors thus include general as well as specific standards, and relate to contaminants, hygiene, packaging, and labeling. According to the Rice Exporters Association of Pakistan (REAP) (2012), "for consumers, quality encompasses a complete range of visual, sensory and palatability criteria that include impressive appearance of raw as well as cooked rice texture in terms of stickiness/flakiness and appealing aroma."2 Rice is generally classified by grain length or by the ratio of length to width. For simplicity's sake, Pakistan's rice exports can be divided into basmati and non-basmati varieties. Basmati generally fetches a much higher price than non-basmati varieties. ${ }^{3}$

\subsubsection{Constraints to Meeting Quality Standards}

Our main findings are based on interviews with leading rice exporters, including Guard Rice, Reem Rice Mills, and Ideal Rice. ${ }^{4}$ The key constraints identified by the business operators we interviewed are listed below:

- The dearth of effective research on grain development and new varieties

- The poor handling of pre-harvest and post-harvest paddy, which results in high moisture content, leading to numerous quality issues such as the development of aflatoxins

- The lack of accredited local testing facilities for critical tests related to DNA, aflatoxin, heavy metals, genetically modified organisms (GMOs), pesticide residue, and others

\footnotetext{
2 See http://reap.com.pk/links/about_rice.asp

${ }^{3}$ Interview with Abdul Basit, Head of Exports, Guard Rice, Lahore.

4 These firms were represented, respectively, by Abdul Basit (head of exports), Javed Islam Agha (firm owner and cofounder of REAP), and Ahsan Saeed Sheikh (owner and operator).
} 
- The change in pre-shipment inspection (currently handled by the Quality Review Committee (QRC) under the government-controlled Trade Development Authority of Pakistan; since control shifted from REAP to TDAP, exporters' confidence in the QRC has been compromised significantly)

- Inadequate quality and compliance orientation at the grower level, leading to numerous issues for exporters

- The absence of an effective body representing the interests of the supply chain as a whole.

\subsubsection{Obtaining International Certification}

Figure 4 illustrates the procedure for obtaining major international certification such as from the International Organization for Standardization (ISO) and hazard analysis critical control point (HACCP) systems. ${ }^{5}$

\section{Figure 4: Procedure for obtaining major international certification}

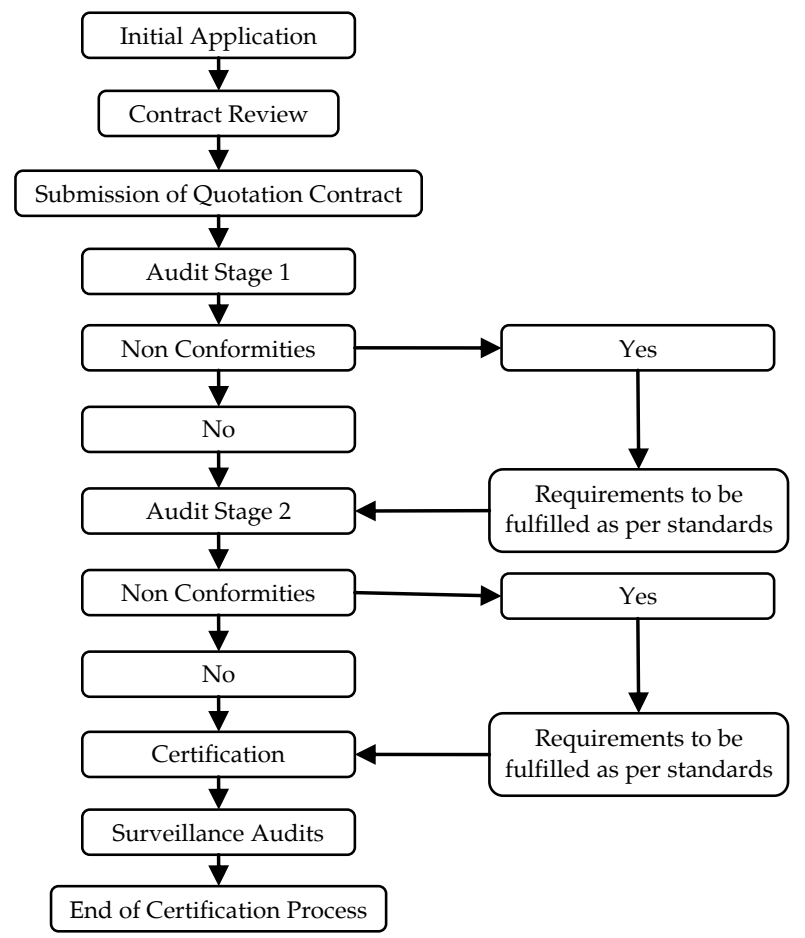

Source: Small and Medium Enterprise Development Authority (n.d.).

\footnotetext{
${ }^{5}$ For further details, see http://www.fao.org/docrep/meeting/008/y5871e/y5871e0m.htm
} 
Figure 5 provides a general idea of the regulatory framework followed by exporters, who need to comply with buyers' standards, international standards and, in some cases, industry-specific standards (e.g., Nike and Ikea in the case of textiles). Rice exporters may need to comply with country-specific standards such as those laid down by the Saudi Standards, Metrology and Quality Organization (SASO) (for exporting rice in to Saudi Arabia).

Figure 5: Regulatory framework for exporters

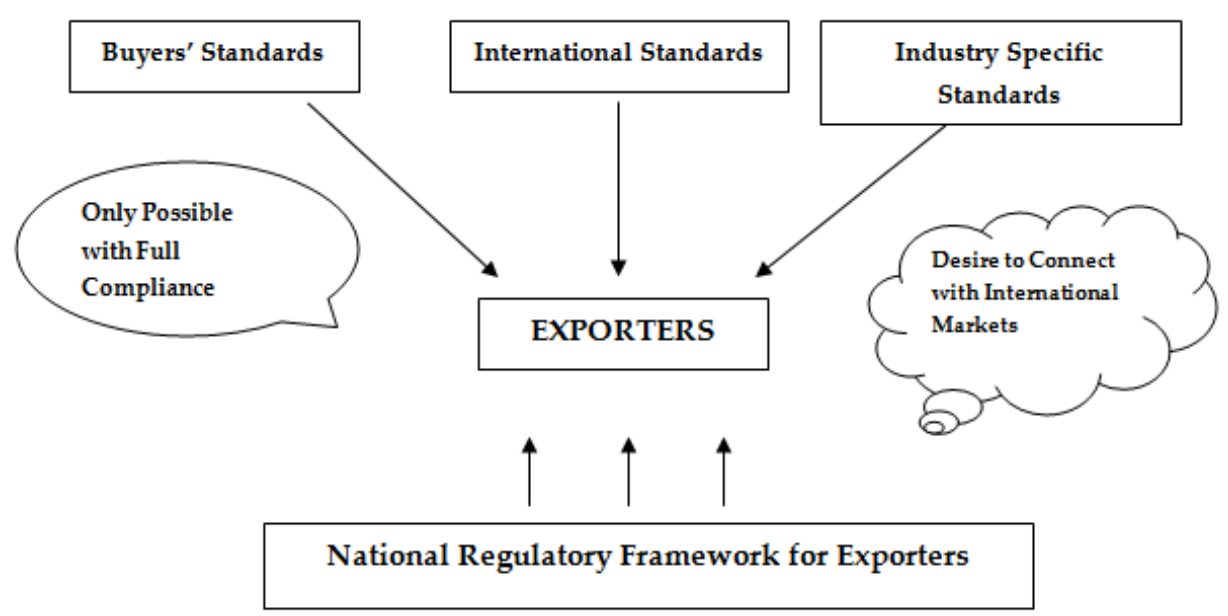

\section{Standards and Requirements for Textiles and Rice}

Some of the main international testing standards for textiles are laid down by the American Society for Testing and Materials, the American Association of Textile Chemists and Colorists, the British Standards Institute, the ISO, the European Committee for Standardization, the Electrotechnical Commission, and the Technological Association of the Pulp and Paper Industry (see Appendix).

Rice testing requirements can vary from market to market. Some of the more common testing requirements for Europe include tests related to:

- Aflatoxin

- DNA

- Heavy metals

- GMOs

- Pesticide residue 
The inspection criteria include product specifications and physical characteristics such as:

- Moisture percentage

- Average grain length

- Broken grains

- Purity

- Shriveled percentage (immature grain)

- Damaged grains (discolored, field damage, heat damage, fungus)

- Foreign content (e.g., insects, stones, etc.)

- Tip breakage

- Whiteness

\section{Quality Assurance Infrastructure in Pakistan}

Tables 4 and 5 provide a generic capability matrix for the textiles and rice sectors. It is evident that international quality service providers are generally considered more reliable and are often a nominated source for testing, inspection, and certification requirements because they are globally recognized and have the requisite capacity and networks.

Table 4: Major players in textile quality assurance in Pakistan

\begin{tabular}{|c|c|c|c|c|}
\hline \multirow[b]{2}{*}{ Organization } & \multicolumn{3}{|c|}{ Capability } & \multirow[b]{2}{*}{ Origin } \\
\hline & Testing & Inspection & Certification & \\
\hline $\begin{array}{l}\text { SGS Consumer Testing } \\
\text { Services }\end{array}$ & $\sqrt{ }$ & $\sqrt{ }$ & $\sqrt{ }$ & International \\
\hline Intertek Pakistan & $\sqrt{ }$ & $\sqrt{ }$ & $\sqrt{ }$ & International \\
\hline $\begin{array}{l}\text { Bureau Veritas Consumer } \\
\text { Products Services }\end{array}$ & $\sqrt{ }$ & $\sqrt{ }$ & $\sqrt{ }$ & International \\
\hline Textile Testing International & $\sqrt{ }$ & $\sqrt{ }$ & $x$ & National \\
\hline $\begin{array}{l}\text { Pakistan Textile Testing } \\
\text { Foundation }\end{array}$ & $\sqrt{ }$ & $\sqrt{ }$ & $\sqrt{ }$ & National \\
\hline $\begin{array}{l}\text { Pakistan Council of } \\
\text { Scientific and Industrial } \\
\text { Research }\end{array}$ & $\sqrt{ }$ & $\sqrt{ }$ & $x$ & National \\
\hline In-house laboratories & $\sqrt{ }$ & $x$ & $x$ & National \\
\hline
\end{tabular}

Source: Pakistan Standards and Quality Control Authority. 
Table 5: Major players in rice quality assurance in Pakistan

\begin{tabular}{|c|c|c|c|c|}
\hline \multirow[b]{2}{*}{ Organization } & \multicolumn{3}{|c|}{ Capability } & \multirow[b]{2}{*}{ Origin } \\
\hline & Testing & Inspection & Certification & \\
\hline SGS & $\sqrt{ }$ & $\sqrt{ }$ & $\sqrt{ }$ & International \\
\hline Intertek Pakistan & $\sqrt{ }$ & $\sqrt{ }$ & $\sqrt{ }$ & International \\
\hline Bureau Veritas & $\sqrt{ }$ & $\sqrt{ }$ & $\sqrt{ }$ & International \\
\hline Eurofins & $\sqrt{ }$ & $\sqrt{ }$ & $x$ & International \\
\hline $\begin{array}{l}\text { Agriculture - Industry - } \\
\text { Marine Survey and } \\
\text { Inspection Group }\end{array}$ & $\sqrt{ }$ & $\sqrt{ }$ & $\sqrt{ }$ & International \\
\hline e-Rice Lab & $\sqrt{ }$ & $\sqrt{ }$ & $\sqrt{ }$ & National \\
\hline $\begin{array}{l}\text { National Institute for } \\
\text { Biotechnology and Genetic } \\
\text { Engineering }\end{array}$ & $\sqrt{ }$ & $\sqrt{ }$ & $x$ & National \\
\hline $\begin{array}{l}\text { Pakistan Council of } \\
\text { Scientific and Industrial } \\
\text { Research }\end{array}$ & $\sqrt{ }$ & $\sqrt{ }$ & $\sqrt{ }$ & National \\
\hline $\begin{array}{l}\text { Nuclear Institute for } \\
\text { Agriculture and Biology }\end{array}$ & $\sqrt{ }$ & $x$ & $x$ & National \\
\hline In-house laboratories & $\sqrt{ }$ & $\times$ & $\times$ & National \\
\hline
\end{tabular}

Source: Pakistan Standards and Quality Control Authority.

\section{Policy Recommendations}

Based on our findings, the following measures would help the textiles sector improve its compliance with international certification standards:

- Investing in research and development (R\&D) in cotton crop production to improve yield and quality.

- Investing in human resource development at all levels, including leadership and management training for entrepreneurs.

- Seeking joint ventures with technically advanced and mature players such as China, Sri Lanka, and Turkey.

- Encouraging textile firms to hire and train women workers for garments and knitwear production-a step the government should, in turn, facilitate.

- Facilitating travel by foreign buyers.

- Promoting cluster development for sub-sectors within textiles. 
- Encouraging big players across different sectors of the industry to form strategic partnerships (holding companies) capable of reaching a size/scale of operations comparable with that of regional competitors.

- Promoting effective public-private partnerships to improve Pakistan's image as a high-quality supplier of textiles and apparel.

- Introducing a national quality award in Pakistan along the lines of the Malcolm Baldrige National Quality Award in the US; the government could support this with financial and nonfinancial rewards.

The following measures would help the rice sector improve its compliance with international certification standards:

- The sector should focus on result-oriented R\&D in grain development and new varieties of rice.

- The government should enact laws that deal with the proper pre- and post-harvest handling of paddy and launch awareness campaigns at the grower level to highlight the benefits of doing so.

- The government could also offer soft loans for the establishment and improvement of storage facilities for paddy.

- National and local testing and inspection facilities should seek globally recognized accreditation.

- $\quad$ The QRC should function independently of the TDAP.

- For pre-shipment inspections, recognized third parties such as SGS should be added to the list of approved service providers (in addition to the QRC).

- The government should encourage the export of branded rice by offering soft loans and other incentives.

- The sector should establish an effective body that represents the interests of the whole sector and has global outreach. This would facilitate R\&D and help register new varieties. The proposed body should work in coordination with the public sector to improve awareness at the farmer level and help formulate a comprehensive code of conduct and/or regulations for the entire rice supply chain. 


\section{References}

All Pakistan Textile Mills Association. (2014). Pakistan textile statistics. Retrieved from http://www.aptma.org.pk/Pak_Textile_Statistics/repo.asp

ASTM International. (2014). ASTM International: Standards worldwide. Available from http:/ / www.astm.org/

British Standards Institute. (2014). Standards, training, testing, assessment, and certification. Available from http:/ / www.bsigroup.com

Codex Alimentarius Commission. (1996). Codex Alimentarius: Cereals, pulses, legumes and derived products and vegetable proteins (vol. 7, pp. 53-60). Rome: Food and Agriculture Organization and World Health Organization.

European Committee for Standardization. (2014). European Committee for Standardization. Available from http://www.cen.eu

Food and Agriculture Organization and World Health Organization. (2004, October). Second FAO/WHO global forum of food safety regulators: Building effective food safety systems. Retrieved from ftp:/ /ftp.fao.org/docrep/fao/meeting/008/y5871e/y5871e00.pdf

International Electrotechnical Commission. (2014). Welcome to the IEC. Available from http:/ / www.iec.ch

International Organization for Standardization. (n.d.). ISO - International Organization for Standardization. Available from http:/ / www.iso.org

Pakistan, Ministry of Finance. (2012). Pakistan economic survey 2011-2012. Islamabad: Author.

Pakistan, Ministry of Finance. (2013). Pakistan economic survey 2012-2013. Islamabad: Author.

Pakistan Standards and Quality Control Authority. (n.d.). Pakistan Standards and Quality Control Authority. Retrieved from http://www.psqca.com.pk/NEP/\%5B10\%5D\%20Laboratories \%2 0in\%20Pakistan\%20i.htm 
Small and Medium Enterprise Development Authority. (n.d.). Compliance with international standards (Guidelines for textile industry). Lahore: Author.

Technological Association of the Pulp and Paper Industry. (2014). TAPPI. Available from http:// www.tappi.org

World Bank. (2014). World development indicators [Database]. Available from http:/ /data.worldbank.org/data-catalog/world-developmentindicators 


\section{Appendix}

Table A1: Testing standards for textiles and fabrics

\begin{tabular}{|c|c|}
\hline Standard & Description \\
\hline ASTM D1388 & Measures the stiffness of fabrics, bending length, and flexural rigidity. \\
\hline ASTM D1683 & $\begin{array}{l}\text { Measures the sewn seam strength in woven fabrics by applying a force } \\
\text { perpendicular to the sewn seams. }\end{array}$ \\
\hline ASTM D2061 & Determines the strength of zippers and zipper parts. \\
\hline 2136 & $\begin{array}{l}\text { Fabrics coated with rubber or rubber-like material display increased } \\
\text { stiffening when exposed to decreasing ambient temperatures. This test } \\
\text { employs a simple pass/fail procedure to determine material flexibility } \\
\text { at a specified low temperature. Failure indicates the unacceptability of } \\
\text { the coated fabric for use at that temperature. }\end{array}$ \\
\hline ASTM D2208 & $\begin{array}{l}\text { Determines the breaking strength of leather by the grab method. } \\
\text { Intended for use on light, soft leathers; boarded, sueded, or embossed } \\
\text { leathers tested on a specimen in the form of a rectangle; narrow strap, } \\
\text { welt, lace, and round belt leathers; or other leathers that cannot be } \\
\text { accurately tested using method D2209. Does not apply to wet blue. }\end{array}$ \\
\hline ASTM D2209 & $\begin{array}{l}\text { Determines the load required to rupture a leather test specimen of } \\
1 / 2^{\prime \prime}(12.7 \mathrm{~mm}) \text { width. The load to rupture divided by the original } \\
\text { unstretched cross-sectional area gives the tensile strength. Can be used } \\
\text { for all types of leather that are smooth and firm enough to permit } \\
\text { accurate thickness measurements. }\end{array}$ \\
\hline ASTM D2211 & $\begin{array}{l}\text { Measures the elongation or stretch characteristics of leather produced } \\
\text { by a tensile load. }\end{array}$ \\
\hline ASTM D2212 & $\begin{array}{l}\text { Determines the slit tear resistance of light leathers such as shoe uppers, } \\
\text { gloves, and upholstery. }\end{array}$ \\
\hline ASTM D2213 & apressibility of sole leather. \\
\hline ASTM & $\begin{array}{l}\text { Measures the tearing strength of textile fabrics by th } \\
\text { rip) procedure using a recording CRE-type tensile te }\end{array}$ \\
\hline AST & $\begin{array}{l}\text { Measures fabric stretch and growth of knitted fabrics intended for } \\
\text { applications requiring low-power stretch properties. }\end{array}$ \\
\hline ASTM D3107 & $\begin{array}{l}\text { Determines the amount of fabric stretch, fabric growth, and fabric } \\
\text { recovery of fabrics woven in whole or in part from stretch yarns after a } \\
\text { specified tension and extension. }\end{array}$ \\
\hline ASTM L & $\begin{array}{l}\text { Determines peel adhesion of reinforcing fabrics that are bonded to } \\
\text { rubber compounds. Applicable to either woven or parallel cord textile } \\
\text { structures from both natural and manmade fibers and to parallel steel } \\
\text { cord structures. }\end{array}$ \\
\hline ASTM D4704 & $\begin{array}{l}\text { Determines the tearing strength of leather by measuring the force } \\
\text { required to tear a specimen cut perpendicular to the surface. }\end{array}$ \\
\hline ASTM D4705 & $\begin{array}{l}\text { Determines the stitch tearing resistance of leather, using a double-hole } \\
\text { tear. Particularly applicable to lightweight leathers. }\end{array}$ \\
\hline ASTM D4786 & $\begin{array}{l}\text { Determines the stitch-tearing strength of leather with a tear originating } \\
\text { from one hole. Particularly applicable to heavy leather. }\end{array}$ \\
\hline
\end{tabular}




\begin{tabular}{|c|c|}
\hline Standard & Description \\
\hline ASTM D4831 & $\begin{array}{l}\text { Intended for use on all types of leather to determine the load required } \\
\text { to tear a leather strap fastened in a buckle. }\end{array}$ \\
\hline ASTM D5034 & $\begin{array}{l}\text { Grab and modified grab test procedures to determine the breaking } \\
\text { strength and elongation of most textile fabrics. Provision is made for } \\
\text { wet testing. }\end{array}$ \\
\hline ASTM D5035 & $\begin{array}{l}\text { Raveled-strip and cut-strip test procedures to determine the breaking } \\
\text { force and elongation of most textile fabrics. Provision is made for wet } \\
\text { testing. }\end{array}$ \\
\hline ASTM D5170 & $\begin{array}{l}\text { Measures the peel strength of hook-and-loop touch fasteners using a } \\
\text { recording CRE tensile testing machine. }\end{array}$ \\
\hline ASTM D5587 & $\begin{array}{l}\text { Measures the tearing strength of textile fabrics by the trapezoid } \\
\text { procedure using a recording CRE-type tensile testing machine. }\end{array}$ \\
\hline ASTM D5733 & $\begin{array}{l}\text { Measures the tearing strength of nonwoven fabrics by the trapezoid } \\
\text { procedure using a recording CRE tensile testing machine. }\end{array}$ \\
\hline ASTM D5735 & $\begin{array}{l}\text { Measures the tearing strength of nonwoven fabrics by the tongue } \\
\text { (single-rip) procedure using a recording CRE tensile testing machine. }\end{array}$ \\
\hline ASTM D6077 & $\begin{array}{l}\text { Measures the tearing load of nonwoven fabrics by the trapezoid } \\
\text { method for leather. }\end{array}$ \\
\hline ASTM D6571 & $\begin{array}{l}\text { Measures compression resistance and recovery properties of any type } \\
\text { of high-loft nonwoven fabric using a simple, economical applied static } \\
\text { weight-loading technique. }\end{array}$ \\
\hline ASTM D6614 & $\begin{array}{l}\text { Determines the amount of fabric stretch and fabric growth after a } \\
\text { specified extension and held for a specified time. }\end{array}$ \\
\hline ASTM D6644 & $\begin{array}{l}\text { Measures the resistance of the bridge of a sew-through button to a } \\
\text { steadily increasing strain. }\end{array}$ \\
\hline ASTM D6775 & $\begin{array}{l}\text { Determines the breaking strength and elongation of textile webbing, } \\
\text { tape, and braided materials using a split-drum type specimen clamp. }\end{array}$ \\
\hline ASTM D6797 & $\begin{array}{l}\text { Measures the bursting strength of woven and knitted textiles taken } \\
\text { from rolls of fabric or fabric taken from garments. }\end{array}$ \\
\hline BS 3356:1990 & Determines the bending length and flexural rigidity of fabrics. \\
\hline BS 3424-5:1982 & For coated fabrics. Methods 7A, 7B, and 7C. Determines tear strength. \\
\hline BS 4098:1975 & $\begin{array}{l}\text { Determines thickness, compression, and recovery characteristics of } \\
\text { textile floor coverings. }\end{array}$ \\
\hline BS 6906-8:1991 & $\begin{array}{l}\text { Geotextiles: determines sand-geotextile frictional behavior by direct } \\
\text { shear. }\end{array}$ \\
\hline $\begin{array}{l}\text { BS EN } \\
12242: 2000\end{array}$ & Touch-and-close fasteners: determines peel strength. \\
\hline $\begin{array}{l}\text { BS EN } \\
13542: 2001\end{array}$ & $\begin{array}{l}\text { Manufactured articles filled with feather and down: determines the } \\
\text { compressibility index of clothing. }\end{array}$ \\
\hline $\begin{array}{l}\text { BS EN } \\
13895: 2003\end{array}$ & Textiles and monofilaments: determines tensile properties. \\
\hline $\begin{array}{l}\text { BS EN 1875- } \\
3: 1998\end{array}$ & $\begin{array}{l}\text { Rubber- and plastic-coated fabrics: determines tear strength using } \\
\text { trapezoidal method. }\end{array}$ \\
\hline $\begin{array}{l}\text { BS EN 1876- } \\
1: 1998\end{array}$ & Rubber- or plastic-coated fabrics: low temperature tests, bending test. \\
\hline
\end{tabular}




\begin{tabular}{|c|c|}
\hline Standard & Description \\
\hline $\begin{array}{l}\text { BS EN } \\
1897: 2001\end{array}$ & $\begin{array}{l}\text { Geotextiles and geotextile-related products: determines compressive } \\
\text { creep properties. }\end{array}$ \\
\hline $\begin{array}{l}\text { BS EN 29073- } \\
\text { 3:1992, ISO } \\
\text { 9073-3:1992 }\end{array}$ & Nonwovens: determines tensile strength and elongation. \\
\hline $\begin{array}{l}\text { BS EN ISO } \\
\text { 10319:1996, ISO } \\
10319: 1993\end{array}$ & Geotextiles: wide-width tensile test. \\
\hline $\begin{array}{l}\text { BS EN ISO } \\
10321: 1996, \text { ISO } \\
10321: 1992\end{array}$ & Geotextiles: tensile test for joints/seams by wide-width method. \\
\hline $\begin{array}{l}\text { BS EN ISO } \\
10618: 2004\end{array}$ & Carbon fiber: determines tensile properties of resin-impregnated yarn. \\
\hline $\begin{array}{l}\text { BS EN ISO } \\
12957-2: 2005\end{array}$ & Geosynthetics: determines friction characteristics; inclined plane test. \\
\hline $\begin{array}{l}\text { BS EN ISO } \\
13431: 1999\end{array}$ & $\begin{array}{l}\text { Geotextiles and geotextile-related products: determines tensile creep } \\
\text { and creep-rupture behavior. }\end{array}$ \\
\hline $\begin{array}{l}\text { BS EN ISO } \\
13934-1: 1999\end{array}$ & $\begin{array}{l}\text { Textiles: tensile properties of fabrics; determines maximum force and } \\
\text { elongation at maximum force using the strip method. }\end{array}$ \\
\hline $\begin{array}{l}\text { BS EN ISO } \\
13934-2: 1999\end{array}$ & $\begin{array}{l}\text { Textiles: tensile properties of fabrics; determines maximum force using } \\
\text { the grab method. }\end{array}$ \\
\hline $\begin{array}{l}\text { BS EN ISO } \\
13935-1: 1999\end{array}$ & $\begin{array}{l}\text { Textiles: seam tensile properties of fabrics and made-up textile articles; } \\
\text { determines maximum force to seam rupture using the strip method. }\end{array}$ \\
\hline $\begin{array}{l}\text { BS EN ISO } \\
13935-2: 1999\end{array}$ & $\begin{array}{l}\text { Textiles: seam tensile properties of fabrics and made-up textile articles; } \\
\text { determines maximum force to seam rupture using the grab method. }\end{array}$ \\
\hline $\begin{array}{l}\text { BS EN ISO } \\
13937-2: 2000\end{array}$ & $\begin{array}{l}\text { Textiles: tear properties of fabrics; determines tear force of trouser- } \\
\text { shaped test specimens (single-tear method). }\end{array}$ \\
\hline $\begin{array}{l}\text { BS EN ISO } \\
13937-3: 2000\end{array}$ & $\begin{array}{l}\text { Textiles: tear properties of fabrics; determines tear force of wing- } \\
\text { shaped test specimens (single-tear method). }\end{array}$ \\
\hline $\begin{array}{l}\text { BS EN ISO } \\
13937-4: 2000\end{array}$ & $\begin{array}{l}\text { Textiles: tear properties of fabrics; determines tear force of tongue- } \\
\text { shaped test specimens (double-tear test). }\end{array}$ \\
\hline $\begin{array}{l}\text { BS EN ISO } \\
14125: 1998\end{array}$ & Fiber-reinforced plastic composites: determines flexural properties. \\
\hline $\begin{array}{l}\text { BS EN ISO } \\
1421: 1998\end{array}$ & $\begin{array}{l}\text { Rubber- or plastic-coated fabrics: determines tensile strength and } \\
\text { elongation at break. }\end{array}$ \\
\hline $\begin{array}{l}\text { BS EN ISO } \\
\text { 2062:1995 }\end{array}$ & $\begin{array}{l}\text { Textiles: yarns from packages; determines single-end breaking force } \\
\text { and elongation at break. }\end{array}$ \\
\hline $\begin{array}{l}\text { BS EN ISO 252- } \\
1: 1999\end{array}$ & $\begin{array}{l}\text { Textile conveyor belts: adhesive strength between constitutive } \\
\text { elements; methods of test. }\end{array}$ \\
\hline $\begin{array}{l}\text { BS EN ISO 283- } \\
1: 2000\end{array}$ & $\begin{array}{l}\text { Textile conveyor belts: full thickness tensile testing; determines tensile } \\
\text { strength, elongation at break, and elongation at the reference load. }\end{array}$ \\
\hline $\begin{array}{l}\text { BS EN ISO } \\
3376: 2002\end{array}$ & $\begin{array}{l}\text { Leather: physical and mechanical tests; determines tensile strength and } \\
\text { percentage extension. }\end{array}$ \\
\hline $\begin{array}{l}\text { BS EN ISO } \\
3377-1: 2002\end{array}$ & $\begin{array}{l}\text { Leather: physical and mechanical tests; determines tear load (single- } \\
\text { edge tear). }\end{array}$ \\
\hline
\end{tabular}




\begin{tabular}{|c|c|}
\hline Standard & Description \\
\hline $\begin{array}{l}\text { BS EN ISO } \\
3377-2: 2002\end{array}$ & $\begin{array}{l}\text { Leather: physical and mechanical tests; determines tear load (double- } \\
\text { edge tear). }\end{array}$ \\
\hline $\begin{array}{l}\text { BS EN ISO } \\
4674-1: 2003\end{array}$ & $\begin{array}{l}\text { Rubber- or plastic-coated fabrics: determines tear resistance (constant } \\
\text { rate of tear methods). }\end{array}$ \\
\hline $\begin{array}{l}\text { BS EN ISO } \\
505: 2000\end{array}$ & Textile conveyor belts: determines tear propagation resistance. \\
\hline $\begin{array}{l}\text { BS EN ISO } \\
\text { 5079:1996 }\end{array}$ & $\begin{array}{l}\text { Textiles: determines breaking force and elongation at break of } \\
\text { individual fibers. }\end{array}$ \\
\hline $\begin{array}{l}\text { BS EN ISO } \\
9073-4: 1997\end{array}$ & Textiles: nonwovens; determines tear resistance. \\
\hline $\begin{array}{l}\text { BS EN ISO } \\
9073-7: 1998\end{array}$ & Textiles: nonwovens; determines bending length. \\
\hline $\begin{array}{l}\text { BS ISO } \\
3341: 2000\end{array}$ & $\begin{array}{l}\text { Textile glass: yarns; determines breaking force and breaking } \\
\text { elongation. }\end{array}$ \\
\hline $\begin{array}{l}\text { BS ISO } \\
3342: 1995\end{array}$ & Textile glass: mats; determines tensile breaking force. \\
\hline $\begin{array}{l}\text { BS ISO } 3597- \\
2: 2003\end{array}$ & $\begin{array}{l}\text { Textile glass-reinforced plastics: determines mechanical properties on } \\
\text { rods made of roving-reinforced resin (flexural strength). }\end{array}$ \\
\hline $\begin{array}{l}\text { BS ISO 3597- } \\
3: 2003\end{array}$ & $\begin{array}{l}\text { Textile glass-reinforced plastics: determines mechanical properties on } \\
\text { rods made of roving-reinforced resin (compressive strength). }\end{array}$ \\
\hline $\begin{array}{l}\text { BS ISO } \\
4606: 1995\end{array}$ & $\begin{array}{l}\text { Textile glass: woven fabrics; determines tensile breaking force and } \\
\text { elongation at break by the strip method. }\end{array}$ \\
\hline EN 14689 & $\begin{array}{l}\text { Leather: physical and mechanical tests; determines bagginess, creep, } \\
\text { and relaxation. }\end{array}$ \\
\hline
\end{tabular}

Note: $\mathrm{CRE}=$ constant rate of extension.

Source: ASTM International (2014). 
Table A2: Different testing and international inspection standards

\section{International testing standards}

\section{Textiles}

- ASTM International (www.astm.org)

- British Standards Institute (www.bsigroup.com)

- International Organization for Standardization (www.iso.org)

- European Committee for Standardization (www.cen.eu)

- International Electrotechnical Commission (www.iec.ch)

- Technological Association of the Pulp and Paper Industry (www.tappi.org)

- AATCC is the world's leading not-for-profit association serving textile professionals. It provides test method development, quality control materials, and professional networking for thousands of members in 60 countries throughout the world.

- Azo dyes (banned in Europe)

- Customer-specific

\section{Rice}

- Codex Alimentarius Commission (Codex 198-1995)

\section{International inspection standards}

\section{Textiles}

- As the leading US standards and conformity assessment system, the American National Standards Institute empowers its members and constituents to strengthen the US marketplace position in the global economy while helping to assure the safety and health of consumers and the protection of the environment.

- ASTM International (formerly known as the American Society for Testing and Materials) is a globally recognized leader in the development and delivery of international voluntary consensus standards. Today, some 12,000 ASTM standards are used around the world to improve product quality, enhance safety, facilitate market access and trade, and build consumer confidence.

- Intertek provides comprehensive services for all textile and apparel inspection, testing, and certification needs to help deliver the highest-quality products.

- 4-point American system for acceptable quality limit (AQL)

- Saudi Standards, Metrology and Quality Organization

- Customer-apecific (e.g. Levis, Nike, Wal-Mart)

Rice

- Food and Agriculture Organization, World Health Organization 